\title{
Government departments to promote the development of urban common distribution policy research
}

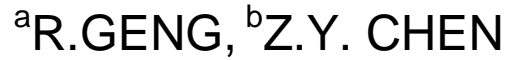 \\ ${ }^{a}$ Reseach Institute of Highway Ministry of Transport, Beijing, china \\ ${ }^{\mathrm{b}}$ Reseach Institute of Highway Ministry of Transport, Beijing, china
}

KEYWORD: Transportation Engineering; Joint Distribution; Public Policy

ABSTRACT: According to the demand characteristics of urban common distribution pattern development, combined with China's current logistics management system and the development environment, this paper puts forward a new objectives, selection of the policy tools and policy to government in promoting the rapid development of the joint distribution of the city direction, recommendations.

\section{THE DIRECTION OF GOVERNMENT TO PROMOTE THE DEVELOPMENT OF URBAN COMMON DISTRIBUTION}

The government should focus on the joint distribution relationship between the distribution of the city and the following.

With the development of urban economy

Balancing the supply capability of urban common distribution system and the demand of urban economic development to the urban logistics.

With efficient use of resources

To improve the energy efficiency of urban logistics system and the value of resource utilization, pay attention to improving the efficiency of logistics system, optimize the use of nonrenewable resources, reduce the consumption of resources.

With the protection of the ecological environment

To promote the development of urban logistics system, based on the natural environment and ecological balance, at the same time to meet the needs of the contemporary environment and ecological composite system.

With equalization of social services

To protect the city logistics system to improve and develop the results and benefits, benefit to the whole society members, pay more attention to the common distribution development level of urban areas, weak areas.

\section{GOAL OF GOVERNMENT TO PROMOTE THE DEVELOPMENT OF URBAN COMMON DISTRIBUTION}

The government's goal of governance in urban distribution can be summarized as "two high and three low", which is not only a high level of service, high logistics efficiency, low economic cost, low social and environmental costs.

the high level of service

Refers to the high quality to complete the task of every link of the joint distribution of the city, at the time of booking the cargo integrity lossless sent to the customer designated locations, according to the agreed upon completion of high quality logistics services, such as: timely delivery, supply information support, business consulting, technical support and after sale services.

the high efficiency of distribution

On the basis of satisfying certain logistics service level, the logistics cost is the lowest, or the best logistics service level can be achieved with a certain distribution cost. 


\section{the low of social and environmental costs}

Urban logistics system operation process will interfere with the urban residents, such as noise, traffic jam, emissions, the low of social costs is that in a certain quality of service and economic costs under the premise, as far as possible to reduce the influence of urban logistics of urban social environment.

\section{the low of economic cost}

Urban common distribution of the various links will be the logistics costs, such as distribution, transportation, loading and unloading, circulation and processing of the cost of the total, that is, the total cost of the distribution system. Minimum economic cost is one of the important goals of distribution enterprises. Industry governance should be the pursuit to provide policy support, and make full use of the enterprise quest to guide the joint distribution of the city to the "two highs and two low" direction of development.

\section{THE GOVERNMENT'S POLICY TOOL TO PROMOTE THE DEVELOPMENT OF URBAN COMMON DISTRIBUTION}

Table 1 government intervention in the joint distribution model

\begin{tabular}{|c|c|c|c|c|c|}
\hline & enterprise & Distribution model & Core power & Dominant party & $\begin{array}{l}\text { Government } \\
\text { intervention }\end{array}$ \\
\hline 1 & \multirow{4}{*}{$\begin{array}{l}\text { Production } \\
\text { and trade en- } \\
\text { terprises self } \\
\text { distribution }\end{array}$} & $\begin{array}{l}\text { Single production en- } \\
\text { terprise }\end{array}$ & $\begin{array}{l}\text { Promote enterprise } \\
\text { product sales }\end{array}$ & $\begin{array}{l}\text { manufacturing en- } \\
\text { terprise }\end{array}$ & weak \\
\hline 2 & & $\begin{array}{l}\text { Single business en- } \\
\text { terprise }\end{array}$ & $\begin{array}{l}\text { Ensure the supply of } \\
\text { internal stores }\end{array}$ & $\begin{array}{l}\text { Business enter- } \\
\text { prise }\end{array}$ & weak \\
\hline 3 & & $\begin{array}{l}\text { Multiple production } \\
\text { or business enter- } \\
\text { prise joint }\end{array}$ & $\begin{array}{l}\text { Mutual benefit and re- } \\
\text { ciprocity, lowering the } \\
\text { efficiency }\end{array}$ & $\begin{array}{l}\text { Production (busi- } \\
\text { ness) business }\end{array}$ & weak \\
\hline 4 & & online retailers & $\begin{array}{l}\text { Security platform car- } \\
\text { go service, enhance the } \\
\text { influence }\end{array}$ & online retailers & weak \\
\hline 5 & \multirow{2}{*}{$\begin{array}{l}\text { Logistics en- } \\
\text { terprise pro- } \\
\text { fessional dis- } \\
\text { tribution }\end{array}$} & $\begin{array}{l}\text { Single logistics en- } \\
\text { terprise }\end{array}$ & $\begin{array}{l}\text { mprove the efficiency } \\
\text { of professional logis- } \\
\text { tics enterprises }\end{array}$ & $\begin{array}{l}\text { Professional lo- } \\
\text { gistics enterprises }\end{array}$ & weak \\
\hline 6 & & $\begin{array}{l}\text { Multiple logistics en- } \\
\text { terprises }\end{array}$ & $\begin{array}{l}\text { Integration of re- } \\
\text { sources, reduce costs }\end{array}$ & $\begin{array}{l}\text { Alliance Enter- } \\
\text { prise }\end{array}$ & weak \\
\hline 7 & \multirow{2}{*}{$\begin{array}{l}\text { Logistics sta- } \\
\text { tion uniform } \\
\text { distribution }\end{array}$} & $\begin{array}{l}\text { Large distribution } \\
\text { center }\end{array}$ & $\begin{array}{l}\text { Improve the operating } \\
\text { efficiency of the sta- } \\
\text { tion yard }\end{array}$ & Station operator & Strong \\
\hline 8 & & $\begin{array}{l}\text { Terminal distribution } \\
\text { site }\end{array}$ & $\begin{array}{l}\text { Integration needs, im- } \\
\text { prove efficiency }\end{array}$ & Station operator & weak \\
\hline 9 & $\begin{array}{l}\text { The informa- } \\
\text { tion technol- } \\
\text { ogy enterprise } \\
\text { car distribu- } \\
\text { tion }\end{array}$ & $\begin{array}{l}\text { Information technol- } \\
\text { ogy companies }\end{array}$ & $\begin{array}{l}\text { Expansion of informa- } \\
\text { tion platform usage }\end{array}$ & $\begin{array}{l}\text { Information tech- } \\
\text { nology companies }\end{array}$ & weak \\
\hline 10 & \multirow{4}{*}{$\begin{array}{l}\text { Specific re- } \\
\text { source distri- } \\
\text { bution }\end{array}$} & $\begin{array}{l}\text { Source of supply } \\
\text { (starting point) }\end{array}$ & $\begin{array}{l}\text { Ease congestion, im- } \\
\text { prove air quality }\end{array}$ & $\begin{array}{l}\text { Logistics enter- } \\
\text { prises }\end{array}$ & Strong \\
\hline 11 & & $\begin{array}{l}\text { Destination (termin- } \\
\text { al) concentration }\end{array}$ & $\begin{array}{l}\text { Ease congestion, im- } \\
\text { prove air quality }\end{array}$ & $\begin{array}{l}\text { Logistics enter- } \\
\text { prises }\end{array}$ & Strong \\
\hline 12 & & $\begin{array}{l}\text { Specific channel re- } \\
\text { source }\end{array}$ & $\begin{array}{l}\text { Ease congestion, im- } \\
\text { prove air quality / re- } \\
\text { liability }\end{array}$ & $\begin{array}{l}\text { Channel man- } \\
\text { agement enter- } \\
\text { prise }\end{array}$ & Strong \\
\hline 13 & & Chartered pass & Ease congestion & $\begin{array}{l}\text { Certified enter- } \\
\text { prises }\end{array}$ & Strong \\
\hline
\end{tabular}




\section{The intervention of the government to promote the joint distribution model}

Integrated the types and features of the government can choose policy instruments, and a section analysis of various common distribution mode of operation characteristics and applicable conditions, especially the core power of the development of the model, this section focuses on the analysis on the government to promote different model of joint distribution of involvement degree.

\section{The government 's policy intervention in different modes of distribution}

Comprehensive government to promote the joint distribution mode of intervention degree analysis, and the government all elements of the joint distribution of policy tools selection, analysis of degree of involvement of the government's policy of different joint distribution models of the various elements, as shown in table 4-3. "-" said participation is weak, "tick" said participation is strong, "tick tick" said intervention is strong.

Table 2 Analysis on the policy intervention of different factors in different modes of distribution

\begin{tabular}{|c|c|c|c|c|c|c|c|c|}
\hline & enterprise & Distribution model & $\begin{array}{l}\text { infra- } \\
\text { struc- } \\
\text { ture }\end{array}$ & $\begin{array}{l}\text { Trans- } \\
\text { port } \\
\text { equip- } \\
\text { ment }\end{array}$ & $\begin{array}{l}\text { Distri- } \\
\text { bution } \\
\text { subject }\end{array}$ & $\begin{array}{l}\text { Distri- } \\
\text { bution } \\
\text { organi- } \\
\text { zation }\end{array}$ & $\begin{array}{l}\text { New } \\
\text { tech- } \\
\text { nology } \\
\text { appli- } \\
\text { cation } \\
\end{array}$ & $\begin{array}{l}\text { Gov- } \\
\text { ernment } \\
\text { inter- } \\
\text { vention }\end{array}$ \\
\hline 1 & \multirow{4}{*}{$\begin{array}{l}\text { Production } \\
\text { and trade } \\
\text { enterprises } \\
\text { self distri- } \\
\text { bution }\end{array}$} & $\begin{array}{l}\text { Single production } \\
\text { enterprise }\end{array}$ & & $\sqrt{ }$ & & & $\sqrt{ }$ & weak \\
\hline 2 & & $\begin{array}{l}\text { Single business en- } \\
\text { terprise }\end{array}$ & & $\sqrt{ }$ & & & $\sqrt{ }$ & weak \\
\hline 3 & & $\begin{array}{l}\text { Multiple produc- } \\
\text { tion or business en- } \\
\text { terprise joint }\end{array}$ & & $\sqrt{ }$ & & & $\sqrt{ }$ & weak \\
\hline 4 & & online retailers & & $\sqrt{ }$ & & & $\sqrt{ }$ & weak \\
\hline 5 & \multirow{2}{*}{$\begin{array}{l}\text { Logistics } \\
\text { enterprise } \\
\text { profes- } \\
\text { sional dis- } \\
\text { tribution }\end{array}$} & $\begin{array}{l}\text { Single logistics en- } \\
\text { terprise }\end{array}$ & $\sqrt{ }$ & $\sqrt{ }$ & $\sqrt{ }$ & $\sqrt{ }$ & $\sqrt{ }$ & weak \\
\hline 6 & & $\begin{array}{l}\text { Multiple logistics } \\
\text { enterprises }\end{array}$ & $\sqrt{ }$ & $\sqrt{ }$ & $\sqrt{ } \sqrt{ }$ & $\sqrt{ }$ & $\sqrt{ }$ & weak \\
\hline 7 & \multirow{2}{*}{$\begin{array}{l}\text { Logistics } \\
\text { station uni- } \\
\text { form dis- } \\
\text { tribution }\end{array}$} & $\begin{array}{l}\text { Large distribution } \\
\text { center }\end{array}$ & $\sqrt{ } \sqrt{ }$ & $\sqrt{ }$ & $\sqrt{ }$ & $\sqrt{ } \sqrt{ }$ & $\sqrt{ }$ & Strong \\
\hline 8 & & $\begin{array}{l}\text { Terminal distribu- } \\
\text { tion site }\end{array}$ & $\sqrt{ }$ & $\sqrt{ }$ & $\sqrt{ }$ & $\sqrt{ }$ & $\sqrt{ }$ & weak \\
\hline 9 & $\begin{array}{l}\text { The infor- } \\
\text { mation } \\
\text { technology } \\
\text { enterprise } \\
\text { car distri- } \\
\text { bution }\end{array}$ & $\begin{array}{l}\text { Information tech- } \\
\text { nology companies }\end{array}$ & & & $\sqrt{ }$ & & $\sqrt{ }$ & weak \\
\hline 10 & \multirow{4}{*}{$\begin{array}{l}\text { Specific } \\
\text { resource } \\
\text { distribu- } \\
\text { tion }\end{array}$} & $\begin{array}{l}\text { Source of supply } \\
\text { (starting point) }\end{array}$ & $\sqrt{ } \sqrt{ }$ & $\sqrt{ }$ & $\sqrt{ } \sqrt{ }$ & $\sqrt{ }$ & $\sqrt{ }$ & Strong \\
\hline 11 & & $\begin{array}{l}\text { Destination (ter- } \\
\text { minal) concentra- } \\
\text { tion }\end{array}$ & $\sqrt{ } \sqrt{ }$ & $\sqrt{ }$ & $\sqrt{ } \sqrt{ }$ & $\sqrt{ }$ & $\sqrt{ }$ & Strong \\
\hline 12 & & $\begin{array}{l}\text { Specific channel } \\
\text { resource }\end{array}$ & $\sqrt{ } \sqrt{ }$ & $\sqrt{ } \sqrt{ }$ & $\sqrt{ } \sqrt{ }$ & $\sqrt{ } \sqrt{ }$ & $\sqrt{ }$ & Strong \\
\hline 13 & & Chartered pass & $\sqrt{ }$ & $\sqrt{\sqrt{ }}$ & $\sqrt{ } \sqrt{ }$ & $\sqrt{\sqrt{ }}$ & $\sqrt{ }$ & Strong \\
\hline
\end{tabular}




\section{GOVERNMENT TO PROMOTE THE DEVELOPMENT OF URBAN COMMON DISTRIBUTION POLICY RECOMMENDATIONS}

Joint distribution is a complex system engineering, its healthy and rapid development, not only depends on the participation of enterprises to jointly promote the subject, but also requires the government and relevant industry organizations to give some guidance and support. According to the current China's existing government and industry associations of the division of responsibilities, the influence of the industry and urban distribution demand of government and industry associations in the policy recommendations to promote the urban common distribution development work.

To give full play to the role of industry associations to increase the joint distribution of publicity

First, industry associations should give full play to the organization, discipline, service and supervision function, strengthen the dissemination of ideas and technical guidance, the seminars, training, introduce the advanced practices and successful experiences of the domestic and foreign joint distribution, deepen the understanding of the industry of common distribution;

Second, during the joint distribution operation, the industry association should play a coordinating role, to provide the corresponding technical support and industry guidance for the public distribution platform, coordination of multi stakeholder conflict;

Third, appliances, food, cosmetics and other professional associations to strengthen communication and cooperation with enterprises in the industry, understand the needs of industry common delivery, to actively explore the construction in line with the characteristics of the industry common delivery system.

\section{To strengthen market management, and create a good market environment}

First, speed up the revision of the "road transport regulations and related rules and regulations, cities management and distribution into the regulation of road transportation management category; to establish and perfect the mechanism of joint distribution market access, the industry regulator, clear the service quality standard and other related requirements, give full play to the government in the city of a common distribution market system construction guidance function and market supervision, to standardize and guide the orderly development of the joint distribution of the city;

Second, clear the city common distribution of goods transportation management contents, rules and standards to determine the joint distribution of the urban management behavior norms and legal responsibility, disclosure of trade secrets, unfair competition, disturb the market behavior for pressure blow, guide the urban co distribution enterprises to standardize the development of;

Third, strengthen the supervision of the common distribution vehicle, developed in line with the requirements of the operation of joint distribution models of standard and main technical parameters of, actively guide and promote enterprises to use the standard distribution models, accelerate urban common distribution standard of vehicle, van, identification of management.

Fourth, promote road freight market credit system construction, improve the integrity of the system, to establish the "good faith" information database, to strengthen the relevant departments to "good faith" information docking, support urban common distribution enterprises to participate in the integrity of law-abiding rating, promote industry norms and self-discipline.

the development of supporting the central city freight traffic policy

First, in serious traffic congestion in the area, the reasonable means to strengthen the commercial gathering area of restricted access, improve into commercial gathering area distribution costs, effectively promote the implementation of the joint distribution; at the same time, in the analysis of the distribution of total demand, structure, spatial distribution based on, reasonably determine the restricted access area specific scope and limits the passage of time and avoid the emergence of the phenomenon of "one size fits all";

Second, to strengthen the planning and construction of traffic control area distribution facilities, reasonable layout of freight vehicles handling, parking and other facilities, and constantly improve the level of business gathering area distribution services; 
Third, improve the distribution system of distribution vehicles, the optimization of the city's common distribution of vehicle control measures, to establish a reasonable coordination mechanism between the city's joint distribution capacity and traffic control.

\section{The planning of the urban common distribution node network}

First, promoting the city and accelerate the formation of three cities and distribution node of logistics park, distribution center - the city end of the joint distribution frame node system, strengthen the adjustment and integration of distribution center, continue to strengthen the public function of the distribution center;

Second, for urban distribution demand total quantity, structure, flow research, know the situation of city common distribution of total demand, goods structure, spatial distribution, time distribution and so on, determine the size of the joint distribution center of the city and location;

Third, increase the construction of the city end distribution node, relying on the campus, community, through the construction of common distribution network and information platform, the integration of the end of the distribution of resources, improve the last one hundred meters of the distribution efficiency.

\section{the introduction of preferential measures to promote the development of joint distribution}

First, increase the support to the joint distribution center construction, accelerate the construction of fast moving consumer goods, such as fruits and vegetables of different types of specialized urban joint distribution center, guide the commerce and trade circulation enterprises and supermarket use third-party logistics distribution center, allocate centers and other public infrastructure, focused on the use of third-party City joint distribution professional capacity resources, increase the common development and distribution enterprises policy support;

Second, encourage conditional cities and enterprises to explore the night joint distribution mode, the city to implement "the night distribution of common distribution enterprises and commercial enterprises, properly solve the annoying problem of premise, giving appropriate economic compensation. Third, perfect "camp to add" policy, the implementation of to engage in joint distribution of the third party logistics enterprises preferential tax policies, reducing the chain enterprises set up joint distribution organization of tax burden, eliminate the institutional barriers to joint distribution chain enterprises engage in.

\section{To speed up the development of third party joint distribution enterprises}

First, to make full use of the city center of logistics resources and freight vehicle entry permit control means, the joint distribution as the starting point, focusing on cultivating brand awareness, market share is larger, the distribution network sound of the large-scale professional modern logistics and distribution enterprises;

Second, encourage enterprise logistics distribution extend service field, support for third party logistics enterprises, pharmaceutical, cold fresh products, dangerous goods, etc. enterprise of integration of resources, to promote the professionalization of the formation of joint distribution subject and market;

Third, in a timely manner to carry out the city of joint distribution leading enterprise demonstration projects, to guide and encourage the distribution of the main body to the operation of intensive, large-scale, professional direction.

to promote the development of the logistics informatization and standardization of urban co distribution

Urban construction joint distribution logistics public information platform, strengthen docking upstream and downstream supply chain information, ensuring smooth flow of information, of urban common distribution based information data collect and release, integrate social resources, encourage enterprises to introduce and independent innovation to use advanced science and technology, so as to create conditions for the implementation of the joint distribution.

To strengthen the standardization construction of distribution logistics, to establish a unified, scientific and standardized standard system. Through the development of technical standards for logistics distribution system internal facilities, machinery and equipment, special tools, the operation of vari- 
ous types of packaging, storage, handling, transportation, and other standards, and as the characteristics of modern logistics logistics information standard, in the participants to establish mutual dialogue and mutual collaboration platform and ties, thus reducing conflicts, improve efficiency.

\section{REFERENCE}

Deng Ai-min, Wang Shao-mei, Zheng Hong-yu. The Analysis of City Distribution Forming Mechanism [J] Wuhan University of Technology ( Social Science Edition) December 2005

$\mathrm{Xu}$ Tong-lian, Sun Bao-feng, Fu Zhong-ning, Xu Hong-mei. Study on the Model of Fractal Management of Joint Distribution [J] Journal of Highway and Transportation Research and Development Vol. 23 No. 3 Mar. 2006

Han Li-juan. Research on the Mode of Urban Joint Distribution [D] Wuhan University of Technology Dec. 2013

Tang Xiao-chun, Wu Yin-long, Zhao Liang. The Joint Distribution of World's Development and the Development Prospects of China. [J] Journal of Highway and Transportation Research and Development Jul 2013

Zong Gao-qin. Research on Terminal Joint Distribution for Small and Medium E-Commerce Enterprises [D] Beijing Jiaotong University Mar. 2015 